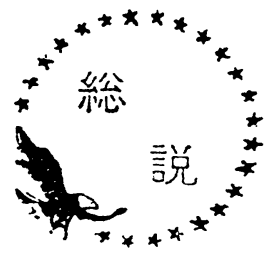

I. ま えがき

今日，世界のあらゆる地域でエネルギー消費はます ます増大している。また現在われわれはいろいろな形 でエネルギーを豊富にしかも安価に利用できる環境下 にある。とくに第 2 次大戦後の世界注先進諸国に款い ては戦災復興, 経済再建につづいてより高い生活水準 求めて，また低開発諸国注おいては新たな工業化の 努力がはらわれはじめエネルギーの重要性は戦前にも ましてますます高まつてきている。1963年の世界全体 の商業用 1 次エネルギーの消費量注急速に変貌しつつ あるエネルギー流体化の影響にもより，43 億 $\mathrm{t}(7,000$ $\mathrm{kcal}$ 石炭換算）程度に達し，1 人当たりエネルギー 消費量も世界平均で約 $1.5 \mathrm{t}$ に達した。

\section{II. 経济の発展とエネルギー}

1. 現在のエネルギー状況

一般に経済規模が搪大し, 生活が向上するにつれて エネルギー需要が高まり，また逆に 1 人当たりのエネ ルギー消費の大きい国は経済発展度も高い。しかし同 時に国民所得が同じ程度の水準にありながら産業構造 の違いにより, エネルギー消費量について相当の差違 がみられる。各国別の国民所得の増大とエネルギー消 費量の増大との関係は自然条件の相違にも左右される が，打打む坟工業化を達成した国もしくは工業化の途 上にある国の方が，農業に特化している国や低開発国 といわれている国よりも，国民所得単位当たりの生産 亿要したエネルギ一消費量は大きい。

しかしながら一方, 最近の 10 年間では, アメリカ, 西ドイッ,フランスなどの重化学工業化をすでに達し 終つた諸国では，エネルギー消費の伸びが国民所得の 伸びを下回り，逆に工業化の途上にある国もしくは国 民所得水準の比較的低い諸国では，エネルギー消費の 伸びは国民所得の伸びを上廻つている。これは先進諸 国では，エネルギー利用効率の向上やエネルギー消費 の比較的少ない第 3 次産業の比重がましている結果で あると思考される。

つぎに世界のエネルギーの生産と消費がどのような 分布状況になつているかを考察すると地域別のエネル ギー消費水準に大巾な格差があるとともに，地域別に
もまたエネルギーの生産と消費がかい離していること がわかる。たとえば1963年の 1 人当たりエネルギー消 費量は北アメリカでは $8.2 \mathrm{t}$ に対し，アジアでは 0.3 $\mathrm{t}$ と40倍以上の相違がある。また世界の約 $20 \%$ の人口 をもつ北アメリカ地域ゆ西ヨーロッパの工業的先進地 域が世界全体の $60 \%$ \%近くのエネルギーを消費している が，世界人口の約半分を持ち豊富なエネルギー資源に 恵まれているアフリカ, 中近東, アジア, 南アメリカ 諸地域は全部合わせても全エネルギーの $13 \%$ を消費し ているにすぎない。

戦後, エネルギーの消費増加は急速に進展された が，同時に消費構造の変化にも注目すべきものがあ る。世界のエネルギー総消費にしめる石炭の割合は, 毎年ほぼ 1\%ゔつ小さくなつてきた。1950年に汇約60 \%を占めていた石炭は1963年には50\%以下におち，こ れに代わつて1963年には石油が $35 \%$ ，天然ガスが $17 \%$ に達し，使益性や経済性に富む石油系燃料が石炭消費 の伸び悩みを肩がわりし，さらに経済発展にともなう エネルギー需要の増大にこたえている。

2. 石炭・石油の登場から今日まで

18世紀後半からイギリスで始まつた産業革命にとつ て石炭は必須のものであつた。石炭は蒸気機関の燃料 として、ヨーロッパ, アメリカに波及していき産業革 命の動力源になつた。

一方, 石油が近代産業として誕生し, 本格的にエネ ルギーとして登場したのは，今から約 100 年まえのこ とであつた。1859年，アメリカ，ペンシルバニア州に 扔けるドレイクの商業的鉄管掘さくがその始まりであ る。原油生産開始から約半世紀の間は, 灯油と潤滑油 だけが原油から得られる主目的製品であつた。ガソリ ン留分は照明用の油としては引火点が低く, 爆発の危 險があり，その処置にこまつていた。しかし1885年ダ イムラーベンツによるガソリンエンジンの発明は，ガ ソリンを石油製品の一つとするとともに自動車の大量 生産はガソリン需要を増大させ, 以来今日の石油産業 は，これを再出発点として多様な石油製品の用途を開 拓していった。戦後の画期的変化は, 石油化学原料, ガス製造原料に用いられるほか，副産されるガスも利 
用されている。そしてこのような石油産業の発展を支 えた要困として, タンカーの大型化による輸送コスト の大巾な低減と，著るしい技術革新が行なわれている 油田開発技術の発達がある。

\section{III. 石 油の需給}

\section{1. 世界の石油消費}

先にも述べたごとく石油消費の歷史は古い。その消 費量は，1859年，石油が近代産業として登場してから 今日まで，約 250 億 $\mathrm{k} l$ に上つている。

今世紀に入つてから今日までの世界の石油消費の増 加は, 1900 年から 1930 年まではおおむ敉率 7 8\% 前後のテンポで増加し，1930年から1945年までは年率 4 5\% と増勢が若干衰えたが，第 2 次大戦後は再び増 勢に転じ，1950年までは 7 8\% に近、年率で増加の 傾向をたどってきた。特に第 2 次世界大戦以後におけ る石油の消費規模は, 固体エネルギーから流体エネル ギーへの波にのり急激に増加した。1946年当時の世界 全体の年間消費量はおお㧍む放 4 億 $\mathrm{k} l$ 程度であつたが, その後は 5 ケ年閒にほぼ 2 億 $\mathrm{k} l \sim 3$ 億 $\mathrm{k} l$ という大巾 な増加を示し, 1964 年には実に 16 億 7,000万 $\mathrm{k} l$ 余り に達し，1950年当時に比較すると実に 2.6 倍以上の増 加となつている。

これを地域別の消費状況でみると，1950年にアメリ カ，カナダを主とする西半球の消費量が世界の $71 \%$ を 占めていたものが，1964年には $48 \%$ に低減し，世界消 費の中心が東半球に移つてきた。すなわち主要消費国 別にみると，アメリカ，カナダなどではその消費増加 のテンポが比較的緩慢であつたのに反し，日本や西ヨ 一ロッパ各国の消費はきわめて急調を示してきた。特 に日本と西ドイッの両国の場合は他に類例のない驚異 的な増加で，この15力年間に日本の場合は約29倍, 西 ドイツの場合は約17倍に達した。またイタリアの約 9 倍の増加をはじめ, 西ヨーロッパ主要国は平均 5.5 倍 に，共産圏諸国も 4.7 倍に達したが，アメリカはわず かに 1.7 倍にすぎず，またカナダ，オーストラリヤの 諸国も世界の平均増加水準にようやく達する程度の微 増であつた。このような各国別の著しい消費増加テン ボの相違によつて，世界石油消費に占めるアメリカの 比重は1950年の60\%から1964年には実に37\%へと大巾 な低落を示した。

製品別消費構成は，アメリカ，カナダと日本や西ヨ 一ロッパ諸国とは全く対照的な傾向がうかがわれる。 すなわち, 前者のうち特にアメリカの場合には, ガソ リンの構成比は依然として製品の約半分を占め, 典型 的なガソリン中心の構造であるのに対し, 西ヨーロッ
パのうちイギリス，フランスおよび西ドイッにおいて は溜出および残渣燃料油（軽油および重油）の比重が 極端に高く, 主要石油製品合計量の70 $80 \%$ の割合を 占め, 特に溜出燃料油 (軽油) の増加傾向に比し, 灯 油の比重が次第に低下しつつ苏る。日本およびイタリ ヤの場合には重質製品（重油）の比重がきわめて高い のが特徵であるが，この期間における比重の変化は少 なかつた。

ガソリン, 灯油, 鐘油および重油の主要製品が最終 的にいかなる分野で消費されてきたか。その消費分野 も時代により，国によつて画一的ではなかつた。その 国のエネルギー源の供給事情や国民経済的な基礎条件 によって，それぞれの差異が生じてきている。

すなわち, アメリカや西ヨーロッパの場合，ガソリ ンの最終消費は自動車, 航空機による輸送用の消費に 集中されており, 灯油注庭用おょび商業用の消費が 圧倒的に多い。軽油（溜出燃料油）はアメリカでは家 庭用消費が約半分を占めているのに対し，西ヨーロッ パではむしろ輸送用や工業用消費が大部分を占めてい る点が目立つている。特に重油の最終消費はアメリカ と西ヨーロッパではかなり異なつた型態を示してき た。たとえば西ヨーロッパでは1953年当時には工業用 よりもむしろバンカー用としての消費が主体で，当時 の重油消費量の約 $2 / 3$ を占めていたが，1963 年には工 業用および電力用などの消費にその地位を置き換えら れた。アメリカの重油消費は, 豊富かつ低廉な石炭や 天然ガスの供給に影響され分散的であつた。

以上のように, 石油製品の最終用途, 、わゆる消費 構造の歴史的な変化は, 国によつて異なつているが, 石油製品が従来のように単に燃料としての消費分野に とどまらず，ヨーロッパ諸国や旦本においてみられる ように, 石油化学や肥料工業などを原料として次第に 大きな消費分野を搪大しつつあることは最近にお括る 石油消費の新しい動向として注目すきべである。

\section{2. 世界の石油需給}

石油消費の 急増, 輸送手段の 発達や石油資源の 探 鉱, 開発などの技術的進歩により, 世界の原油生産も 増加したが，かつて世界最大の原油生産国であつたア メリカを中心とする北アメリカ地域の比重は第 2 次大 戦後は驚くべきテンポで低落し，これに代わって中東 地域の原油生産の躍進は画期的で, 世界の石油地図は 大きく描き変えられてきた。

第 2 次世界大戦後にお预る中東油田開発の一大躍進 と，世界最大の産油国であり輸出国であつたアメリカ が戦後一転して輸入国に転換した二つの事実は，世界 
の石油需給上の大きな構造的な変化をもたらした最大 の要因であつた。その構造的変貌を契機として，その 後の世界の石油需給構造法次第に変化の過程を進んで きたし，さらに最近にいたつて特に注目に值すること はアフリカにおるおる大規模な新油田の開発である。サ ハラ,リビア,ナイジェリアなどに扔汀る活発な開発 活動は, 石油の大消費地ヨーロッパに対し，わずかに 地中海を隔てただけで, 従来の供給源で品つたヴェネ ズェラや中東に対して地理的に有利な位置にあるだけ に, 特にヨーロッパの石油需給構造に, 新たな変化を 与える要因となりつつある。すなわち原油の供給地域 はソ連を除いて中東, カリブ海, 北アフリカの地域に 集約されたといえる。1964年のアメリカ上上記 3 地域 を加えた地域での石油供給量は，自由世界の石油の $87.5 \%$ を占めるのに対して，その 4 地域における消費 は自由世界消費の $50 \%$ で㐫つた。その差の約 $37 \%$ ， 4 億 6,200 万 $\mathrm{k} l$ がその地域以外つ自由諸国に供給され た。

1949年にアメリカが純輸入国に転換した結果, 先進 工業国のほとんど 全部が高い石油輸入依存国となつ た。ヨーロッパ各国および日本では，過去10数年の間 原油輸入依存度の改善は全く実現せず，85〜99\%に達 した。原油の供給先は, アメリカはカリブ海から約 47 $\%$ ，カナダから $20 \%$ とその 3 分の 2 を西半球依存し ている。西ヨーロッパ主要国および日本は中東地域一 の依存度が圧倒的に高く, $75 \%$ ～80\% 汇達し, 西半球 への依存は10\%にすぎない。

石油製品の海外依存状況は一般に各国とも著しく改 善され，消費地精製方式による国内供給体制が一段と 強化されつつある。

3. 世界の石油貿易

世界の石油貿易の構造は第 2 次世界大戦を境として 大きく変貌した。大戦前はアメリカとカリブ海の 2 大 供給源から東半球のヨーロッパ，アジアへの流れが主 流で，1938年の石油貿易量の約 $40 \%$ がカリブ海地域か ら, 約 $30 \%$ がアメリカから輸出されていた。大戦後は アメリカの輸入国への転換と中東の増産によつて, 中 東およびカリブ海の 2 つの大きな流れに変わり, しか も東西両半球の交流が次第にそれぞれの内部の相互貿 易に変わつた。すなわち1964年の石油貿易量は約 8 億 $\mathrm{k} l$, その約半分が中東からで, その $90 \%$ が東半球各国 への供給であつた。

また大戦前は製品貿易が大半であつたが，戦後は原 油貿易汇変わり，1964年には74\%が原油で䒜つた。

戦前の石油貿易が製品貿易であつたことは，原油が
生産地の近くで精製されて消費地に供給されているこ とを示すもので喌るが，戦後法消費地立地製油所の経 済的有利性に上つて消費地精製方式が世界的に推進さ れた。フランケル博士の推定によ礼ば，1965年のアメ リカ, カナダ, ソ連を除く自由世界の精製能力は, 生産地立地製油所は世界全能力の $16.3 \%$ となり, 消費 地精油所注70 $80 \%$ に達するであらうといっている。

4. 主要地域の精製能力

第 2 次世界大戦後, 世界の原油の需要々供給構造の 変化が大きく影響した。また石油の安定確保を図る必

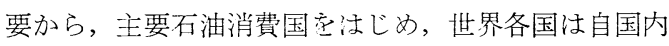
精製方式に急速に変わつていつた。

北米アメリカは世界一の原油生産国であり，また 石油の輸出国であつたので, 生産地製油所の国であつ た。しかし戦後石油輸入国に転じて以降は, 消費地精 油所型に移行したとみることができる。また国内にお いても，原油生産地域のローカル小製油所はスクラッ プされ，次第に大型製油所集約をみつつ每る。アメ リカはガソリン需要比率がきわだつて大きいため, 世 界の他の諸国とは異なり，分ソリン增産のための分解 装置能力の比重がきわめて大きい。

カナダの産油州は西部にあるが, 石油需要は東部に 偏在しているため，同国の精製能力は東部に集中し， 地域消費地製油所型である。

中南米 中南米のなかでもベネズエラ, アルテイル 諸島，トリニダッドなど戦前から盛んに活躍してきた 製油所は生産地製油所型であり,その製品はアメリカ, ヨーロッパの重要な供給源であつた。しかし今日㳄次 第にそのウェイトを下げつつある。一方南米諸国は各 自に国内製油所の建設を進好抒り, 中南米を通観す れば消費地製油所型に変わりつつある。

西ヨーロッパ 戦前の西ヨーロッパはアメリカ, カ リブ海域から石油製品を輸入して佧給してきたが，戦 後急速に国内精製方式すなわち消費地製油所型を形成 した。とくにヨーロッパ大陸にあつては沿岸製油所方 式から内陸の石油需要地製油所の建設が盛んで, これ がために南および北から内陸へ向かつてのパイプライ ン布設の盛行が特徴的である。

アフリカ 戦後大原油資源地として登場してきた北 アフリカにも，また西アフリカの新産油国にも製油所 の建設が進められている。しかし現在のところは，か つてのアメリカ, カリブ海域, 中東にみられたような 製品輸出のための大型製油所建設 (生産地製油所型) の気配はない。むしろ現地需要に応じたものとみられ る。従来イタリア, 南フランスの製油所(中間地製油所 
型）は，このアフリカの石油製品需要を賄つていたの であるがアフリカ各国が自国製油を行ならにつれて， その型態に変化が生じつつある。

中東 中東に建設された製油所はいずれも大型で， 典型的な生産地製油所である。近年は目立つた増設計 画はないが，現在でもヨーロッパおよび極東に対する 製品供給の中心的存在である。

極東・大洋州 日本は消費地製油所型として戦後急 速な精製能力の桩充が図られた。しかし極東の各国， オーストラリアにおいても，自国内精製方式が着々推 進されている。

5. 世界の原油生産

現在，世界各地で原油生産がおこなわれており， 1965年には世界の原油生産量は 17 億5,000万 kl に達し た。地域別には中東地域の生産量が 4 億 8,500 万 $\mathrm{k} l$ に なり始めてアメリカ合衆国の生産量を凌駕し，世界全 体にしめる生産比率も約 $28 \%$ となり，世界最大の原油 供給地域となつた。しかし単一産油国としては，アメ リカ合衆国は依然として 4 億 5,300 万 $\mathrm{k} l$ と世界最大を 誇つている。カナダ，メキシコを含めた北アメリカ地 域の生産量は 5 億 1,800 万 $\mathrm{k} l$, 世界全体の約 $30 \%$ の生 産比率であり，同地域の 1961年〜65年の増加率は 2.5 \%であつた。

新興産油地域アフリカの伸びはいちじるしく，1965 年では, アフリカ地域の生産量は 1 億 2,800 万 $\mathrm{k} l$ と世 界全体の約 7\% をしめた。このうちとくにリビアの産 油量の增加はめざましく，1959年の生産開始以後わず か 7 年にして，世界全体の約 4\% をしめ，イラクにつ ぐ第 8 位の産油国となつた。一方南アメリカ地域のヴ ェネズェラの生産活動は停滞している。1961年〜65年 までの世界全体の生産増加率は $7.8 \%$ であつたが，同 期間のヴェネズェラは $4.3 \%$ と $3.5 \%$ も下䞤つた。こ れは主として原油価格引き下げに対処するためにヴェ ネズェラ政府のとつた企業活動の制限措置などの影響 による。ソ連の生産量は着実に増加しており，1965年 に注2 8,100 万 $\mathrm{k} l$ （世界全体の $16 \%$ ）とアメリカにつ ぐ産油国となつている。インドネシアに代表される極 東, 太洋州の原油生産量は 4,800 万 $\mathrm{k} l$ で世界の $3 \%$ と その割合は小さい。インドネシアは政情不安から1960 年代に入つてから原油生産は伸び悩んでいる。西ヨー ロッパ地域の原油生産量は 1,700 万 $k l$ で, その割合は $1 \%$ にすぎず地域別では最も小さい。

石油生産量の歴史が始まつて以来，1857年から1965 年までの 108 年間にわたる石油生産量の合計（累積生 産量）は世界全体で 272 億 8,000 万 $\mathrm{k} l$ に達した。累積
生産量のうち，第 2 次大戦後の1951年から1965年まで の 15 年間で全量の $62 \%$ にたる 169 億 8,300 万 $\mathrm{k} l$, 1951年以前の 93 年間で約 $38 \%$ にある 102 億 9,700 万 $\mathrm{k} l$ を生産した。累積生産量を地域別にわけるとアメリ 力合衆国が 125 億 8,500 万 $\mathrm{k} l$ で全体の $46 \%$ をしめ, ついで中東地域が 45 億 8,300 万 $\mathrm{k} l$ で $17 \%$ ，ソ連が 31 億 9,700 万 $\mathrm{k} l$ で $12 \%$ ，ヴェネズェラが 31 億 4,900 万 $\mathrm{k} l$ で $11.5 \%$ となつている。中東, ソ連, ヴェネズ エラが開発の時期が異なるにもかかわらずほぼ同程度 の累積生産量を示していることは興味深い。アフリカ は最近の生産増加はめざましいが, 新興産油地域であ るため 4 億 4,200 万 $\mathrm{k} l$ と累積生産比率はきわめて小 さい。アジア, 太洋州地域（インドネシアの生産量が しめる割合が大きい) は 7 億 8,600 万 $\mathrm{k} l$ で $3 \%$ 近くを しめている。

6. 世界の確認埋蔵量

世界の確認埋蔵量は, 1965 年には 580 億 2,900 万 $\mathrm{l}$ の規模に達している（海底埋蔵量はそのうち 15\%)。 全確認埋蔵量のうら中東地域が 362 億 9,600 万 $\mathrm{k} l$ と $62.5 \%$ をめ豊富な石油資源をもつている。その他の 産油地域は中東地域に比してはるかに少ない。北アメ リカ（アメリカ合鼻国とカナダ）地域は64億 4,900万 $\mathrm{k} l$ と $11.1 \%$ をしめ, アメリカ合衆国単独では 49 億 8,500 万 $\mathrm{k} l, 8.6 \%$ である。アメリカ合衆国では探鉣 活動の停滞により1960年代に入つてから埋蔵量の規模 は減少の傾向さえみせている。ソ連, 東欧地域の比率 は 57 億 6,700 万 $\mathrm{k} l$ で $10.0 \%$ である。ヴェネズェラで は探鉱の新利権を認可しない最近のヴェネズェラ政府 の政策もあつて, 確認埋蔵量の増加はほとんどわずか である。しかしヴェネズェラはなおかつ 27 億 6,100 万 $\mathrm{k} l(4.8 \%)$ と世界の主要な原油埋蔵地帯である。新興 産油地域のアフリカは資源の賦存状況が広範囲に搜查 されていないにもかかわらず，ヴェネズエラを上廻る 36 億 5,400 万 $\mathrm{k} l$ を有し, 世界の $6.3 \%$ をしめている。 極東，太洋州の埋蔵量は 17 億 7,300 万 $\mathrm{k} l, 3.1 \%$ で あり，このうちインドネシアのしめる割合は地域全体 の $60 \%$ 弱と最も大きい。

1961年〜65年の確認埋蔵量の純増加分は139億6,700 万 $\mathrm{k} l$ であつた。この増加分のうち中東地域が 89 億 2,200 万 $\mathrm{k} l(64.0 \%)$ ともつとも大きな役割をはたし ている。アフリカ地域が 21 億 2,800 万 $\mathrm{k} l$ (15.3\%), Y連, 東欧地域 18 億 4,000 万 $\mathrm{k} l(13.2 \%)$ がこれに つぎ，アメリカ合衆国，ヴェネズエラの寄与率は小さ W。

つぎに地域別にみた可採年数いわゆる $R / P$ (確認埋 
蔵量/生産量)をみると, 中東地域が龙大な生産量に もかかわらず豊富な埋蔵量を有しているため, 74.8 と最も大きく, 極東, 太洋州がこれにつぎ 36.9 であ る。アメリカの $R / P$ は過去 10 年間以上にわたつて 11 〜13の值を示し, ヴェネズェラは 1958 年の 17.7 を境 にして下降に転じ 1965 年には 13.7 となつた。アフリ カは 1959年 では約 130 となつていたが，その後の生 産量の大巾な増加の結果, 現在は 28.5 と激減してい る。

以上の結果, 1965 年の世界全体の $R / P$ は 33.1 と なり，これを最近の年間でみるとわずかながら減少の 一途をたどつているといえる。

\section{7. 日本の石油需給}

日本の石油は, 産油地域において古くから薪, 菜種 油の代替物として実用に供せられてきたが，近代的商 品として全面的に搪がつてきたのは, 明治維新後, 欧 米からのランプの翰入とその普及以降のことである。

こうして, 石油は灯油時代に端を発して, 現在では内 燃機関用，加熱用，原料用，潤滑用などわが国のあら ゆる産業活動，民生向上に寄与してきた。

明治時代 日本の石油需要は, 明治初期に灯油市場 として登場し, 電灯が普及する明治後期にいたるまで つづいた。ガソリン, 軽油, 重油, 潤滑油の用途はほ とんど開発されず，ごく限られた用途に使用されただ けである。その供給は輸入品と国産原油からの製品に よつて賄われた。な拈当時の産油, 精製地域の大半が 新潟などであつた。

大正時代 明治後期から電灯の普及により，これま での灯油中心の消費構造注次第に変化し, ガソリン, 軽油および重油の需要が著増した。これは, 内燃機関 の発達にともなつて, 第 1 次世界大戦後の自動車の普 及, 発達と外航船への重油焚用への転換のためで, ま た軧油は漁業用の石油発動機船への利用開発のためで ある。また次第に軍事的重要性も加わり,これらの需 要に対する供給体制としては国内の精製活動が活発化 し，石油製品の大半は国産により賄われた。しかし， 国産に代わつて廉価な外国産原油の輸入量が著増して いった。

昭和時代 大正時代にひきつゔき,ガソリン, 軽 油, 重油, 潣滑油などは時代の要求とともに需要は増 加していつた。一方供給は, 外油社の製品輸入攻勢に 対抗して, 石油精製能力の増強, 新鋭設備の設置が行 なわれた。しかし国産原油による自給率は, 依然低下 傾向をつづけ，昭和 5 年においては $35 \%$ 程度になり， 輸入原油への依存率が増加した。また当時の消費構造
は，今日上同様重油が最も大きかつたが，国内精製に よる重油の生産得率は非常に小さく, 大量の輸入重油 によりまかなわれた。

1931年（昭和 6 年） 満州事変の勃発によつて, わ が国も準戦時体制をしき, 軍事的目的から石油は統制 品目の対象となり, 石油業法が制定された。さらに, 支那事変抢よび六東亜戦争の勃発により, 石油に対す る民間消費規制は強まり, 石油販売取締規則, 石油專 売法などの統制法規が制定された。このため，民需は 抑えられ，1937年（昭和12年）をピークとして国内消 費割当は大宋に減少していった。

一方，国産原油は国策にそつて増産につと的たが， 増産を急ぐ两まり乱掘を招き，1937年をピークとして 再び産油量注下降傾问を示した。したがつ下原㴼の翰 入が急速に增加したが，文那事変勃発後は翰入先であ る米, 英, 蘭との外交関倸の悪化から1938年（昭和13 年)をピークとしてこれまた潮减し，終戦当時には皆 無となつた。なお石油精製業は, 輸入原油の增加にと もないその数も堌え, 石油業法制定時には 35 社を数 え, 立地条什のいい太平洋岸各地に製油所を建設した が，原油供給の統制強化とともに企業合同を余儀なく され，1941年（昭和16年）には8社に統合された。

1945年（昭和20年） 戦争によって壊滅に近に打撃 を受けた石油産業の将来の運命の鍵を占領軍により握 られ, 一時は太平洋岸製油所のスクラップ化も考えら れたが，その後の国際情勢の変化によつて，再び操業 を許可されることになつた。この間の石油需給は,わ ずかな国原原油とアメリカ軍の放出物資やガリオア資 金による翰入製品によつて辛うじて破局を免かれてい た。

1950年（昭和25年）太平洋岸製油所の再開至梁機 として, 石油需要は急増したが, さらにエネルギー革 命による石炭から石油への転換, ナフサ, ジェット然 料油などの新製品の開発によつて需要の増加は拍車を かけられ，今日，エネルギーの大宗をなすにいたつ た。一方これに対する供給面としては, 国産原油によ る自給率はますます低下して $2 \%$ 以下になり，ほとん。 どすべて輸入に依存せざるを得なくなつた。このため 政府としては供給方式として消費地精製主義を採用 し, 再開後から1962年（昭和37年）の自由化まで外貨 割当方式により需給統制が行なわれた。これによりわ が国の石油精製能力は需要の増加とともに著増し, 原 油処理能力は 1965 年末現在において 20 社 36 製油所で 201 万7, 640 b. b.1/日， 1 製油所当り 5 万 6,000 b. b. $\grave{l}$ 日となり, アメリカ, ソ連, についで世界第 3 位の精: 
製能力を有するにいたつた。

なお，主要石油精製会社のうちには，製油所再開と 相前後して, 原油供給の安定確保, 戦時中に生じた技 術的なギャップの理め合わせなどの意味におろて，ア メリカおよびイギリスの大石油会社と資本および技術 などの提携をおこなつたところがあり，外資提携会社 は現在10社におよんでいる。

なお自由化後, 政府は国内石油産業保護㧍よび石油 の安定的かつ低廉な供給確保という見虵から1962年 7 月，石油業法を新た测定した。

原油の供給は，1955年12月「石油資源開発株式会社 法」に基づいて，半官半民の石油資源株式会社が設立 され，国内石油資源の探鉱，開発に力を注ぐことにな つたが，もともと国内資源に艺しいわが国の産油事情 では到底これに期待することは不可能であり，いきお い輸入原油汇依存せざるを得ない。戦前におけるわが 国の輸入原油の供給源は，主としてアメリカであつた が製油所再開後に㧍ける主要供給源は，地理的，量 的，価格的にみて，戦後急速に開発された中東地域に 偏重しており，1965年度においては輸入原油の約 $90 \%$ が中東産原油となつている。

また1960年中東におけるアラビア石油会社の油田開 発の成功を機に，政府は積極的に海外油田の開発推進 をはかり，現在開発中または計画中の地域としては， 中東，インドネシア，アラスカ，カナダなど数個所に およんでいる。

\section{IV.世界のエネルギー}

1. エネルギーの需要予測

需要予測の方法 エネルギーの需要予測には，一般 北認められた分析ルールとか，定形的な方法があるわ けではない。国ごとに，その国の扔かれているさまざ まな経済的，社会的，そして政治的な事情によつて， また分析の対象となるデーターのいかんによつて，そ の方法が大きく異なっている。いずれにしても，過去 および将来におよぶ需要関係の諸データ，两るいは需 要に作用する諸情報を収集し，作成することが需要子 測の基礎となる。また需要を決定する諸要因について も專門家によつていくつかにわかれている。

パトナム (Putnam) は，2000 年と 2050 年の世界人 口を予測し，その 1 人当たりのエネルギーの入力と出 力からエネルギー総需要量を予測する方法をとつてお り，レビー（W.Levy）注外㨀法, 部門積上げ法およ び経済成長との相関法の3つをあげて1975年の予測を 行なつている。またキリン (Quirin) は「エネルギー 消費を決定する最も重要尔基本的要素は人口と国民所
得(GNP)であるとして，地域別に人口増加とGNP の 予測から，1980年のエネルギー総需要量を予測してい る。OECD の報告書 Energy Policy(1966.4)では, 経済成長率との相関によつてエネルギーの総需要量を 予測する方法と，最終消費部門を工業，輸送㧍よび家 庭用その他の三つにわける積上げ方法の三つを採用し ている。1966年世界動力会議東京部会化提出された工 ネルギー需要予測の方法には積上げ方式と時系列によ る外括法, GNP および鉱工業生産などの相関分析法 など計量経済的手法と先進国の過去の成長パターンを 例として後進国の成長パターンを想定する国際比較方 式などが紹介され論議された。

需要予測における問題点 需要予測にはいろいろな 方法があるが，その想定方法のいかんにかかわらず， 予想数值の確実性, 精度の高いか低いかに問題が集約 されるが，そのいずれもが決定的であるとはいえず， それぞれ問題点が多い。たとえば，パトナムの人口 1 人当りの入力および出力による方法では，エネルギ 一の総合使用効率を将来どのように予測するかのむゔ かしさがある。一般に使われる外插法は，長期的な予 測の場合に，過去のわずかな誤差が大きく，拡大され る不適確さがあり，また部門別積上げ方法では基礎デ 一タの不足によつて, 総需要の全容を捉えがたい。と くに後進国の場合には，この方法は不適当である。計 量経済的方法では，経済発展を予測すること自体に困 難さがある。

部門別積上げ方法は上記のような問題点はあるが， エネルギー源別にその需要を予測することができる有 利さも亦る。エネルギー源別の需要予測は，使用效率 の問題と同様にきわめて重要なエネルギ一価格の問題 がある。エネルギー相互の間には，価格による代替性 の高いものがあるためである。

2. エネルギーの需要みとおし

世界のエネルギー需要のみと扎しについては, ここ 数年間に，たとえば OECD や EEC などの公的機関 によるもの，またはエネルギ一経済専門家による需要 予測など数多く発表されてきた。しかし，そのいずれ も予測期間がバラバラであり，基準年次や基礎となる 経済的指数の数值も千差万別の気味があり，また地域 的にみて一般に世界を全体として，そのエネルギ一総 需要を予測しているものは少なくない。またエネルギ 一需要の予測期間は，お就む社基準年次から 15 年ない し20年間をとつているものが比較的多い。

最も長期でかつ全エネルギーを網羅しているものは パトナムの「エネルギー問題の将来」であろら。 
OECD の報告書は 1970年と 1980 年のエネルギー需要 予測を行なつているが，それによると1980年の世界の 1 次エネルギー総需要量は石油換算で 82 億 $\mathrm{t}$ （石炭換 算 101 億 t ）に上る。レビーは，1975年の世界の全エ ネルギー需要量を原油換算で $81,650 \times 10^{3} \mathrm{~B} /$ 日（石炭 換算約 67 億 t ） と予測し，そのうち石油は45\%を占め るであろうとしている。1966年 4 月のラピー報告（修 正版）によれば，1970 年の総需要は石炭換算で 68億 1,000万 t，1980年には 109億 $\mathrm{t}$ に達するとしている。

3. 1 次エネルギーの需要構成とその資源

国連の「World Energy Supplies (196-1964, No. 9)」によれば1964年の世界のエネルギー消費量法石炭 換算で 49 億 6,5000 万 $\mathrm{t}$ ，そのうち固体然料 22 億 2,700 万 $\mathrm{t}$ で $44.9 \%$ ，液体然料は 17 億5,700万 t で $35.4 \%$, 天然ガスおよび輸入ガスは 8 億 7,500万 $\mathrm{t}$ で $17.6 \%$, そして水力, 原子力および輸入電力が約 1 億 $\mathrm{t}$ で $2.0 \%$
となつている。これを1955年と比較すると，世界の工： ネルギー消費は10年間に約54\%増加したが, その消費 増加の大半は, 液体然料および天然ガスによつてまか なわ机，固体然料のシェアが急激に液体然料かよび天 然ガスなどの流体然料に置きかえられつつある。

OECD の報告書によれば，1964 年のアメリカに拈 ける 1 次エネルギーの消費構成は固体然料 $22.2 \%$, 天 然ガス $32.0 \%$, 石油 $43.2 \%$, 原子力 $0.1 \%$, 水力 $2.5 \%$ で，ヨーロッパの OECD 各国では，同じ年に国体然 料 $49.0 \%$, 天然ガス $2.2 \%$, 石油 $44.6 \%$, 原子力 $0.5 \%$, 水力 $3.7 \%$ ，また日本では固体然料 $37.2 \%$ ，天然ガス $1.4 \%$, 石油 $55.5 \%$, 水力5.9\%で, 石油の比重が大き い。原子力は蒡を出しかけた状況である。

これに対して1980年の 1 次エネルギー構成を以上 3 , つの地域についてみると表1のとおりである。

\section{表 1 主要地域の 1 次エネルギー構成 (1980年) 予測} (単位: 100 万 $\mathrm{t}$ 石油換算)

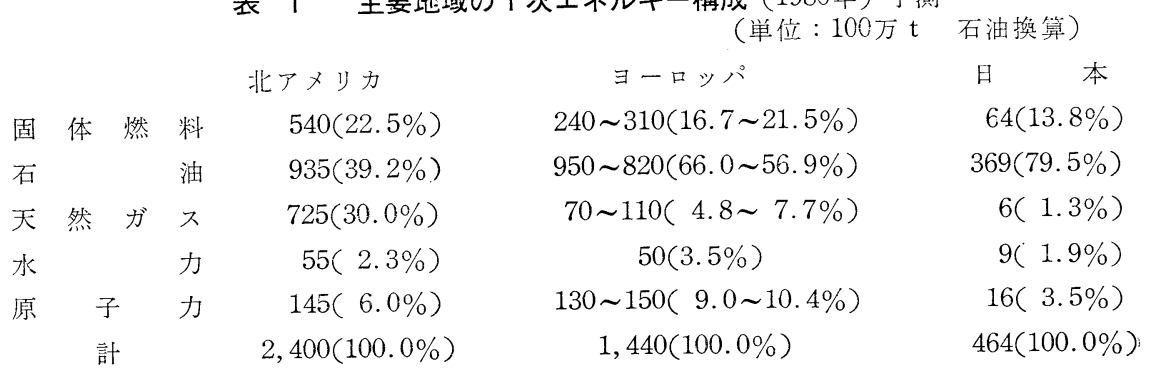

\section{V. 石 油資 源}

1964年末の全世界の原油確認埋蔵量は 543 億 3,700 万 $\mathrm{k} l$, 同年の原油生産量は 16 億 3,500 万 $\mathrm{k} l$ と発表され ている。これによつて可採年数を計算すれば 33.2 年 となる。しかし今日まで原油の需要量は年々増加しつ ゔけてきたし, 将来も需要量は桩大されていくと推定 されている。したがつて1964年の確認埋蔵量を固定的 に考えれば可採年数は当然33年より短縮される。いま かりに将来の原油需要を年率 $5 \%$ づつ増加していくも のとすると，1965年～1985年の21年間の必要原油は現 在の埋蔵量では不足し，1983年で涸渴してしまう計算 になる。また需要増加率が10\%であるとすれば実質的 可採年数は1978年までの14年に短縮される。もつとも これらの可採年数の間には採油技術の進歩があり，地 下からの原油回収率が向上するはづであるから既知確 認埋蔵量の評価は大きくなり, 上述の可様年数もそれ ぞれ延長されることとなる。すなおち将来15２0年間 に現在の水準（世界平均30\%前後）より $40 \%$ に向上し たとするならば可採年数はそれぞれ 27 年，20年と訂正 される。
しかしいずれにしろ石油需要は年々拡大されていく ため，石油を将来にわたつて安定供給していくために は確認埋蔵量を年々拡大していかねばならず，したが. つて課題は将来に向つて原油がどれだけ埋蔵されてお。 り，またそれが現実に発見できるかにかかつてくる。 世界の石油の権威者などの確認埋蔵量の持つ意義, その評価など文献によれば，第 2 次世界大戦後の世界 的石油需要の拡大に応じて新産油国（23ケ国），新油 田がつぎつぎに追加されてきた。1964年末の確認埋蔵 量の約 $13 \%$ が新産油国により占められ，既産油国で戦 後発見された新油田による埋蔵量は約 $44 \%$ を占めてい る。また海底油田の埋蔵量は戦前の零から1964年末で $3.2 \%$ 占めるようになつた。

つぎに確認量はその年の回収技術とコストの下で回 収できると考えられる量を示すものであるから，回収 率が高くなれば, 確認埋蔵量の評価は大きくなる。各 種の意見を総合すると現在の平均回収率 $30 \%$ 前後が， 遠くない将来において50〜 60\%まで向上するものと期 待されている。

つぎに天然原油の資源量でめるが，各権威者の意見， 
数值は区々であり，なた新しく発表されるものは以前 のものより常に大きく評価している。これは年々の探 査技術の向上と, 探查地域の㹡大によつて情報が変化 していく結果によるものと推定される。一例をあげれ ば，L.G.ウイナクスは1948年当時, 世界の可採石油 理蔵量を 777 億 $\mathrm{k} l$ （多くみた場合 1,165 億 $\mathrm{k} l$ ）と推定 していたが, 1958年の発表では過去の生産量 159 億 $\mathrm{k} l$, 確認埋蔵量 516 億 $\mathrm{k} l$, 未発見埋蔵量 1,750 億 $\mathrm{k} l$, 合計 究極可採埋蔵量 2,425 億 $\mathrm{k} l$ とし, 10 年前の 3 倍となつ ている。さらに1962年の同氏の推定值は 3,200 億 $\mathrm{k} l$ と さらに30\%ふえている。

ちなみに世界の石油需要の伸び率と $5 \%$ と仮定すれ ば，1965年から1985年までに必要とする原油は約 610 億 $\mathrm{k} l, 2,000$ 年までの間では 1,645 億 $\mathrm{k} l$ と計算される。 一説によれば世界の原油供給のピークは 2,000 年ごろ で，それ以後の供給は潮減する。しかし回収技術の上 り高い向上によってさらにピークを延ばすことはでき 上うといっている。しかし権威者の大方の見解は，そ の時点から 20 年以上も先のことは確信を持つて断言は できない。石油供給の支配的要因は, 石油を必要とす る度合と資本支出であるとしているし，また将来の賦 存地域は各意見とも中東ということで一致している。 さらに海底油田の開発にも大きな期待を寄せている。

シェールオイル, オイルシェールは世界各地に散在 的に賦存しており，ごく一部の国で小規模で工業的に 原料油を生産しているが，世界の石油需給に寄与する まで発展していないし，またいますぐ発展する可能性 は少ない。

世界のオイルシェールの埋蔵量の $99 \%$ は北アメリカ 地区にあるといわれている。その主力はアメリカのコ ロラド州を中心とする鉱床で, 石油量に換算して 3,000 億 $k l$ 以上といわれ, アメリカの原油確認埋蔵量約 50 億 $\mathrm{k} l$ の60倍に相当する。

オイルシェールは鉱産物で, 地下から探掘採取し, 破砕して乾留する際, 組成変化によつて原油類似物が 生成され，そのガスを冷却することにより液状で回収 できる。アメリカ政府拉よび民閏会社は早くからこの 工業化研究をして㧤り，シェールオイル回収技術にも 各種あるが，今日打打む衩工業化しうる段階まで開発 されている。

シェールオイルはパラフイン分が多いため流動点が 高いので $\left(29^{\circ} \mathrm{C}\right)$ そのままで注パイプ輸送できず, 山 元でビスブレーキングする必要がある。コロラドはア メリカ中部にあるので, オイルは東西いずれかへ転送 洊要する。
シェールオイルの経済性について，アメリカ西海岸 のロスアンゼルスにおける原油との比較計算がある が，現在の原油価格が25 30\%高くなれば競合できる といわれている。また税制上の優遇措置があれば，さ らに有利性を増すと論ぜられている。各種の情報では 数年後には企業化できるといわれており，これはアメ リカの石油政策によつて大きく左右されるが，実現す るとしても急速に世界の石油需給のなかに入つてくる ことはなく，まず直接的にはアメリカの石油需給の範 囲内にとどまるであるう。

サンドタール タールサンドの賦存は, 現在のとこ ろカナダのアルバータ州北部が最大である。各種の推 測があるが，アルバータ州政府は石油換算 660 億 $\mathrm{k} l$ と 見積つており,これは今日の世界原油確認埋蔵量約 500 億 $\mathrm{k} l の 1.3$ 倍に相当する。

タールサンドは地下に賦存し, それ自身に原油類似 物を包含しているが，処理して油分を回収する必要が ある。方法としては熱湯法, 溶剤法があるが, 工業的 には熱湯法が主力となつている。回収油分は比重, 流 動点とも高く, またイオウ分が非常に多いので, 現地 でビスブレーキングと脱硫をほどこしてから市場へパ イプ輸送しなければならない。

その経済性注各種加工費, 輸送費を加えても, アル バータ州の石油市場の中心であるエドモントンに拉い て, 同州の天然原油の市価と競合可能といわれてい る。そのため多くの石油会社が企業化の申請を提出し たが，同州政府はカナダ石油産業の保護と石油需給調 整を理由として一社 (グレート.カカナディアン) にだ け許可を与えた。同社は現在 45, 500b.b.1./日(年産 260 万 $\mathrm{k} l$ ) のサンドタール回収工場を建設中で，1967 年 中に稼働する見込みである。

カナダの石油需給の趨勢からすれば, サンドタール は大きな支援であつて, 天然原油の新発見の動向にも よるが，遂次申請は許可されていくものと思考され る。

以上, 世界の天然原油の供給力は遠い将来は別とし て，中期的には十分あるというのが一般的見解である ようであり, 数值的な判断も技術の向上, 石油価格自 体の動向によつても動くものである。

な㧍，原子力のエネルギー供給に占める地歩も次第 に拡がつてくるであらうが，それは主として熱エネル ギー供給において貢献することとなるので, 石油酒 格競合の結果一部を譲つたとしても, 石油自体の効用 性を失うものではない。石油はより高度な需要である 内燃機関燃料劣るいは化学原料として, 今後ともその 
需要確保はますます重要となつてくるであろう。

第 2 次世界大戦後の石油需要の急堌が天然原油の探 査, 開発を刺㦸し, 同時にシェールオイル, サンドタ 一ルの活用にも努力がはらわれ，その石油資源増加人 の寄与は大きい。

1. 石油の供給

石油の需要 世界の石溜需要の今後の動向について は数多くの予想がなされているが，ここではそのうち の代表的なものについて, 若干の解説を加えることと する。

(1) ラピー報告(正式に注「ヨーロッパ共同体の長期 エネルギーみとおしに関する研究」1953年1月）によ れば，ほとんど一世紀の間，世界の石油消費は 10 年間 倍増の足どりで増加してきた。1962年現在自由世界の 需要注間10億 $\mathrm{t}$ 程度であるが，1975年には年間18億 ～20億 $\mathrm{t}$ に達すると予想されている。米国のエネルギ 一総消費量の増加について專門家の意見注1975年まで の年平均増加率を約 $3 \%$ とし, 石油需要の増加は年平 均約 $2.5 \sim 3 \%$ となると予想（1920年～1960年間5.7\%， 1950年〜1960年間 4\%) している。カナダのエネルギ 一総消費は, 第二次大戦後平均 $9 \%$ 近くで増加し, こ の間石油は平均 $12 \%$ で伸びたが，現在のところ多くの 分析では1975年までの增加率は年平均 4 5\%の間と 考えられている。中米については過去の平均増加率は 6〜7\%であつたり今後10年閒の平均増加率は $4 \%$ 程度 であるが，同国の原油生産に左右されるだろら。南米 については経済成長および生活水準向上の速度が不確 かなため, エネルギー需要とくに石油の需要はきわめ て不安定であり, 過去のエネルギー総需要は15年間に 倍加（年平均 $4.75 \%$ ）し，石油についてもほぼ同值で めつた。

西欧に関しては1960年に発表されたロビンソン報告 が1965年の OEEC 諸国の石油消費を 2 億〜 2 億 4,000 万 $\mathrm{t} ， 1975$ 年のそれを 3 億〜 3 億 8,500 万 $\mathrm{t}$ としてい る。しかし1960年の実績は 1 億 9,000 万 t であつたか ら1965年の予想数值の大きい方の值を大巾に上廻るこ とと考えられ，1975年の西欧全体の消費は 5 億 5 億 4, 000 万 $\mathrm{t}$ と推定される。アフリカ大陸内部の石油消 費は大したものでなく今後も引き続きわずかであろう し，中東についても域内需要はアフリカの場合と似て いる。インド, 極東, 太洋州については全体としてこ の地域の石油消費は著しく増加すると考えなければな らない。

以上のような要素から, ソ連, 東欧諸国, 中共を除 く自由世界の石油需要を先のごとく予想し, さらにつ
ぎのように補足している。

「世界の消費は，1960年から1975年までの15年間に 約 2 倍となるう。これは北米 $3 \%$, その他地域 $7 \%$ の 増加の総括である。後進国の数字は明らかに不確かで あるが，これらの地域では石油以外のエネルギー資源 が豊富なため, 経済成長の加速も, 現在から1975年ま では，世界のみと扎しの変更を招くほど石油の需要の 特徴を変えることはない，と考えられる」

(2) B.P.会長ブリッジマン氏の予想

米国石油協会第43回総会講演によれば，今後10〜20 年間の石油生産量を決定するものは生産能力でなく需 要である。したがつて将来の石油生産量の予想に注, 総エネルギー需要と，そのうちに石油の占める役割を 推測する必要がある。

自由世界のエネルギー需要は, 今後 $3.5 \%$ で堌加す るものとみるのが妥当であるが，これは生活水準の改 善が今後続くと仮定してのことで京る。しかし10〜 15年後にはエネルギー需要増加率は鈍化し，今世紀の 終りには $2 \%$ ま落ちるかもしれない。そして石油の 年平均増加率は1962１970年の間 $5.1 \%$ (北米 $2.8 \%$ その他 $7.2 \%$ ）であり，世紀末頃には $1.7 \%$ (北米 $1.4 \%$ ，その他 $1.9 \%$ )となると推定を行なつている。

輸出入の動向 自由世界の石油輸出入に関しては一 般的につぎのように考えられている。すなわち「北米 の輸入超過傾向が続くので, 中南米を含め西半球全体 として一つの自給自足圈を形成するようになる。ただ し, 中南米の生産主力であるヴェネズェラに大巾な増 産を見込むことはできないから，西半球全体としても また入超となる可能性がある。

中東の豊富な石油資源をもつ東半球は，したがつて 西半球に対し出超となる傾向にあるが，ソ連圏からの 輸入も考慮されなければならない。

しかし，この傾向がどの程度まで発展するかについ ては, 識者の見方は必ずしも一致していない。しかし いずれにしろアメリカの生産推移が今後の輸出入バラ ンスに大きな影響を㧍よぼすことは明らかである。

石油の国際輸送 スエズ動乱の後現在まで, タンカ 一市況は全般的にみて低位安定の様相をしめしてき た。これ海一にタンカー船腹の供給が常に潤沢であ つて，供給不足の可能性がほとんどなくなつてきてい ることと, 第二にタンカーの平均速度の上昇と大型化 による輸送費の低滅にある，大型化による運顀コント 低減のメリットは顕著であつて, 新造船の引下げに大 きく寄与しており，この結果，大型船の新造が相つぎ， 現在では 6 万DWT 以上のものが全世界のタンカーの 
30\%近くを占めている。10万DWT 以上の超大型船は 1965年 6 月末現在で合計 9 隻であるが，同時点におお る発注数は33隻に達している。このような大型化傾向 がどこまで続くかについては, つい最近まで種々の条 件より20 25万DWT が限界ではないかとの見方が有 力であつたが, 現在出この見解は事実によつてくつ がえされるにいたつた。1966 年, ガルフ石油は 30 万 DWT タンカー6隻を発注したし，わが国でも 30 万 DWTタンカー入港可能施設の検討が開始され, 運輸 省当局は 50 万DWTタンカーの基礎設計を行なうと伝 えられている。タンカー市況には差当り上昇要因はな w。

パイプラインは原油生産地帯に おいて油田と翰出 港, あるいは直接需要地とを結ぶのに不可欠の役割を 果している。米国は全世界のパイプライン合計延長の 90 95\%を占め, 国内で輸送される原油の $80 \%$, 石油 製品の $20 \sim 30 \%$ を賄うほどの発達をしめしているし, ソ連では1964年に完成したシベリヤ横断パイプライン （第二バク一油田一イルクーツク間 2,267 マイル)は 世界最長といわれ，将来ナホトカまでさらに 1,460 マ イル延長される可能性があり, わが国への原油輸出と の関連から注目されている。このほか西ヨーロッパ， 東ヨーロッパでは国際的なパイプライン網の発達が活 発に行なわれている。

精製能力の発展 消費地精製主義の発展にともな い, 西ヨーロッパおよび極東の比重が大いに高まり, 需要増加率の低い中東の相対的地位の低下が著しい。 現在の製油能力の地域別構成は, 北米 $42.6 \%$ (うち 米国 $36.5 \%$ ) 南米 $9.4 \%$ 欧州 $28.6 \%$ アフリカ $1.5 \%$, 中近東 $6.4 \%$, 極東 $11.5 \%$ であるが, 新設予定能力は 西欧 $54 \%$ ，極東 $26 \%$ ，中東 $7 \% ，$ アフリカ $4 \%$, 南米 9 \%で，拡張計画を除く新規製油所立地だけをみれば日 本とオーストラリアだけで $70 \%$ を占める。新設抾張計 画は総計 130 であつて55ケ国におよび，このなかには はじめて製油所を持つ国が15ケ国ある。建設計画は 1966年初現在で 2 億 4,000 万 $\mathrm{t}$ をこえる。

石油の供給体制 国際石油産業には高度の集中がみ られ, エッソ, モービル, カルフォルニヤ・スタンダ 一ド, テキサコ, ガルフ (以上米国), シェル (英国, オランダ)，B．P，(英国）の 7 大石油会社が，大きな ウエイトを占めている。これらの会社は1949年にはア メリカを除く自由世界の原油生産量の $88 \%$ 占め, そ の比率は低下の傾向をみせつつも 1961 年にはなお $84 \%$ に達している。第 2 次大戦後はC.F.P.(フランス石 油会社）の操業規模と行動様式が上記 7 大石油会社に
匹敵するまでに発展し，最近では 8 大石油会社とする ことも多い。

しかしながら近年になつて 8 大石油会社以外の石油 会社の重要性が高まり, 原油生産, 精製の分野に㧍い て, 独立系抢よび国営石油会社の比重が増大しつつあ る。

また1960年にはOPEC（石油輸出国機構）が結成さ れ, やがて産油国の利益を代弁する上に大きな役割を 果すことになつた。当初の加盟国はヴエネズエラ，イ ラン, イラク, クエイト, サウジアラビアであつた が, その後カタール, リビア, インドネシアが加盟し ている。OPECは「過㮃産油能力の無制限かつ競争的 乱用」を抑制し，輸出価格を回復するために国別生産 割当を試みており, 操業を行なら石油会社にとつても また消費国にとつても無視できない勢力に発展しつつ ある。

投資 自由世界の石油産業の投資を分析してみる と, アメリカとその他の自由世界に分けると, 以前は 前者の方が多かつたが, 最近は両者ほぼ均衡するにい たつている。投資額の年平均伸び率は, アメリカ 2.5 $\%$, その他自由世界 $8.4 \%$, 自由世界計 $5.5 \%$ となり, アメリカ以外飞おける投資額が急激に増加しているこ とがわかる。投資額の内訳は, 探査開発費が全体の半 分をしめているが，そのらちでも米国の比重が圧倒的 に大きい。残り半分は輸送, 精製, 販売などいわゆる 下流部門への投資である。

将来の投資については世界原油生産の中心がアメリ カから中東や北アフリカへ移動したため東半球の石油 消費の急増と相まつて, 下流部門への投資が増大して いる。15年前には総投資額の 5 分の 2 が下流部門に向 けられていたにすぎないが, 現在この比率は約 2 分の 1 となり，今後さらに上昇すると思われる。

現在石油会社の利益率は低下の傾向をみせており, この傾向が今後も続くとすれば，石油産業の投資にも 影響する可能性があることは否定できないが，今後必 要な投資水準を維持するためには，コスト引下げと生 産性向上によつて適正利益を維持することが可能であ. るといえる。

\section{VI 日本のエネルギーと石油}

\section{1. エネルギー需給}

戦後, 政府は数多くの経済計画を策定または改訂し てきたが，それらの経済計画の活動の裏付けとしての エネルギー需給計画も昭和31年ごろから取りあげてい る。各種経済計画のなかにおけるエネルギー計画は, その手法に精粗はあるが, マクロでみた必要総エネル 
ギー量の測定とミクロでみた各個エネルギーの需給み とおしの積上げとを調整して策定する方法を持つてい る。マイクロ計算の手法としては, 国民総生産 (GNP) あるいは鈗工業生産指数 (IIP) とエネルギー総消費量 との相関によつている。ミクロによる各個エネルギー 種別䨛要の測定に関しては, 競合する石炭と重油との 間に調整を施しているが，ここに安定供給と経済性の 比較検討が考虑され，石炭政策あるいは石油政策がう みだされてきた。

エネルギーの将来需給の予測は，国の経済規模の拡 大および産業構造の変化と密接不可分の関係にある が，昭和31年に策定された通商産業省の経済計画以来 今日までの 10 年間に 4 回の改訂が行なわれ，エネルギ 一計画もその都度改変された。これらの計画とは31年 12月の通商産業省による産業合理化審議会の答申, 33 年 5 月の経済企画庁による経済審議会報告, 35年 9 月 の経済審議会報告（いわゆる所得倍増計画）39年11月 の経済審議会報告（いわゆる中期経済計画）である。 これらの計画に盛られたエネルギーバランスは, 実績 が常にこれを上回り，また各種エネルギーの動向も予 想に反した。その主な原因は, 各計画でみた経済成長 線より実際の経済規模が常に先行したためである。ま た各種エネルギー計画と実績をみれば，エネルギー流 体化の波にのり，石油の割合が他を圧して大きく伸び ていることがわかる。

先に述べたように，エネルギー需要予測は世界でも 日本でも一般に経済成長の度合との相関で推測されて いるが，経済が大きく変動するので予測作業はきわめ てむずかしい。またその需要を，どの種類のエネルギ 一で充足するかを予測し, それにそつたエネルギー政 策を策定し実施していかなければならないのであるか ら, エネルギー需給計画は慎重を要する。エネルギー だけに限つてみても, 消費効率の向上, エネルギー転 換技術の革新, 核然料の組入れ方, 天然ガスの輸入な どがあり, エネルギー供給の内部構造は, 今後 10 年, 20年で大币に変わる可能性がある。しかし世界のエネ ルギー事情を総合的に観察し，また日本のおかれた立 場から思考すれば，当面日本の将来の必要とするエネ ルギー源は, 矢張り石油が中心になつていくであろう。

\section{2. 日本の石油需給}

石油需要と供給 日本の将来の引きつゔく経済発展 を支えるに必要とする 1 次エネルギーのなかで, 石油 のウエイトがより高まつていくことは一般的に認めら れている。通商産業省の総合エネルギ一調查会の試算 (昭和 41 年 7 月)によれば, 昭和 50 年度における石油の
比率は72.7\%, 原子力の比率は $2.1 \%$ とされ 60 年度は 石油 $75.0 \%$ ，原子力 $10.4 \%$ と見積つており，なおこの ほか液化ガス $9.7 \%$ を輸入するとしている。20年度ご ろには日本の1次エネルギーは石油と原子力によつて 全体の $86 \%$ \%占めることになり，日本のエネルギー政 策は, 石油之原子力の安定的供給を目指して急ぎ確立 する必要がある。

総合エネルギー調查会は，石油製品別需要予測も行 なつているが, 将来の石油供給を考える場合, 製品需 要の構成を知ることは肝要である。それによれば将来 の日本の石油製品別需要構成は, 今日とそんなに大き な変化を生じない結果を示している。このこ上は今後 とも同じような精製方式を持続できることを意味して いる。しかし製品間の需要の伸び方に多少の差がある のはもちろんである。その特徴のひとつとしては，ガ ソリン溜分のなかで自䫌車用ガソリンの需要比率が低 くなるのに反して，石油化学用原料ナフサが逆に現在 より暫增していくし，重油については原子力発電が大 巾に組込まれる結果, 現在よりむしろ構成比率は下が るものと考えられている。灯油, 軽油などの中間溜分 の需要構成は現在より若干比率を高めるが, それほど 大きな変化は予想されていない。

将来の日本の石油需要は通商産業省の総合エネルギ 一調查会の試算によれば, 50 年度は約 2 億 $\mathrm{k} l$ で 40 年度 の 7,800 万 $\mathrm{k} l$ の 2.6 倍となり, さらに 60 年度では 3 億 8,500 万 $\mathrm{k} l$ に達し, 50 年度の 1.9 倍の量になるものと 見積つている。この石油量は龙大である。40 年度の 7,800 万 $\mathrm{k} l$ は原油換算 8,500 万 $\mathrm{k} l$ に相当するが, 1964 年 (昭和 39 年) の世界の原油生産量 16 億 4,000 万 $\mathrm{k} l$ に 対し $5.2 \%$ になり，また中東原油生産量 4 億 4,000 万 $k l$ に対比させれば中東の生産量の約 $20 \%$ が日本に輸. 出されていることになる。

将来の世界の石油需要の伸び率と日本の伸び率を勘 案した場合, 一国としてアメリカ, ソ連につぐ大消費 国であること, しかもアメリカ, ソ連が大部分の原油 を自給し, 一部を輸入にまつのと異なり, 日本は原油 をもたない点が弱身であるから, 将来原油の安定確保 については一段と努力を要するところである。

精製能力の拡大 将来必要とする精製能力を原油需 要量から試算すると, 昭和50年度では全国平均稼働率 を $90 \%$ とした場合，約 490 万b.b.l./ 日が必要となり， さらに60年度では約 920 万 b.b.l/日 が必要となる見込 みである。したがつて 41年 3 月末能力 205 万b.b.1./日 との間には, 50 年度までに 285 万b.b.1./日，60年度ま での間には 715 万b.b.1./日 の精製能力の不足を生ずる 
表 2 経済企画庁経済審議会企画部会エネルギー小分科会報告

(中期経佩計画に打けるエネルギー計画) (昭和39年11月) 1次エネルギー供給 $(7,000 \mathrm{kcal}$ 石炭換算 $1,000 \mathrm{t})$

\begin{tabular}{|c|c|c|c|c|c|}
\hline \multirow{2}{*}{ 水 } & \multirow[b]{2}{*}{ 力 } & \multirow{2}{*}{$\overbrace{24,207(12.4)}^{38 \text { 脌 度 }}$} & 43 年 度 & $\overbrace{}^{50 \text { 年 度 }}$ & 60 年 度 \\
\hline & & & $27,650 \quad(8.8)$ & $33,320 \quad(6.3)$ & 38,115 \\
\hline 烣 & 系 & $61,451(31.5)$ & $73,054(23.2)$ & $78,449(14.9)$ & 79,897 \\
\hline 石 & 油 & $102,220(52.4)$ & $204,563(65.3)$ & $395,433(75.0)$ & $771,674(81.4)$ \\
\hline 天 & ガ & $2,908 \quad(1.5)$ & $4,125 \quad(1.3)$ & $7,373 \quad(1.4)$ & $8,773 \quad(0.9)$ \\
\hline 質 & 系 & $4,315 \quad(2.2)$ & $3,625 \quad(1.2)$ & 2,940 & 2,510 \\
\hline 燃 & 料 & $0(0)$ & $385(0.1)$ & 9,200 & 47,705 \\
\hline 今 & 計 & 195,101 & 313,402 & 526,720 & 948,675 \\
\hline 1 人当り & (t/年) & 2.0 & 3.1 & 4.8 & 8.1 \\
\hline
\end{tabular}

表 3 通産省総合エネルギー調査会中間試算（昭和 41 年 8 月）

「総合エネルギー政策のあり方」

(1 次エネルギー供給みとおし (試算) =換算calの単位は 10 兆kcal)

\begin{tabular}{|c|c|c|c|c|c|c|c|c|c|c|c|c|c|}
\hline \multirow[b]{2}{*}{ 実 数 } & \multicolumn{4}{|c|}{ 39年度(実績) } & \multicolumn{3}{|c|}{45 年 度 } & \multicolumn{3}{|c|}{50 年 度 } & \multicolumn{3}{|c|}{60 年 装 } \\
\hline & 位 & 実数 & $\underbrace{\text { 算 }}_{\begin{array}{c}\text { 換 } \\
\mathrm{cal}\end{array}}$ & $\begin{array}{l}\text { 構成比 } \\
(\%)\end{array}$ & 実数 & $\underbrace{}_{\mathrm{cal}_{\mathrm{cal}}^{\text {算 }}}$ & $\begin{array}{c}\text { 構成比 } \\
(\%)\end{array}$ & 実数 & $\underbrace{\text { 算 }}_{\substack{\text { 換 } \\
\mathrm{cal}}}$ & $\begin{array}{c}\text { 構成比 } \\
(\%)\end{array}$ & 実数 & $\overbrace{\begin{array}{c}\text { 換 算 } \\
\text { cal }\end{array}}$ & $\begin{array}{c}\text { 構成比 } \\
(\%)\end{array}$ \\
\hline 力 & 10億kWhr & 69.0 & 16.9 & 11.6 & 82,9 & 20.3 & 8.3 & 89.2 & 21.9 & 6.5 & 96.0 & 235 & 4.1 \\
\hline 原子 力 & " & - & - & - & 5.9 & 1.6 & 0.7 & 30.7 & 7.5 & 2.1 & 245.0 & 60.0 & 10.4 \\
\hline 炭 & 100 万 $\mathrm{t}$ & 68.0 & 42.7 & 29.3 & 78.7 & 50.3 & 20.8 & 84.4 & 55.2 & 16.6 & 82.8 & 53.9 & 9.0 \\
\hline 国内炭 & $"$ & 54.0 & 31.9 & 21.9 & 54.0 & 31.3 & 12.9 & 53.3 & 31.4 & 9.4 & 53.5 & 31.4 & 5.5 \\
\hline 輸入炭 & $" \prime$ & 14.0 & 10.8 & 7.4 & 24.7 & 19.0 & 7.9 & 30.9 & 23.8 & 7.2 & 29.3 & 22.5 & 3.5 \\
\hline 炭 & " & 0.6 & 0.3 & 0.2 & 0.3 & 0.1 & 0.0 & 0.3 & 0.1 & 0.0 & 0.3 & 0.1 & 0.0 \\
\hline 油 & 100 万 $\mathrm{k} l$ & 85.4 & 80.8 & 56.3 & 172.0 & 162.9 & 67.4 & 259.4 & 245.1 & 72.7 & 457.6 & 430.9 & 75.0 \\
\hline 国産原油 & $"$ & 0.7 & 0.7 & 0.5 & 0.7 & 0.7 & 0.3 & 1.0 & 0.9 & 0.4 & 1.0 & 0.9 & 0.2 \\
\hline 輸大原油 & $"$ & 74.2 & 69.7 & 47.7 & 144.6 & 135.9 & 56.2 & 229.5 & 215.8 & 67.5 & 432.6 & 406.7 & 70.8 \\
\hline 製品輸入 & $" \prime$ & 10.5 & 10.4 & 7.1 & 26.7 & 26.3 & 10.9 & 28.9 & 28.4 & 4.8 & 24.0 & 23.3 & 4.0 \\
\hline $\begin{array}{c}\text { 液化石油ガ } \\
\text { (輸) }\end{array}$ & $\begin{array}{l}\text { त } 100 \text { 万 t } \\
\text { 入) }\end{array}$ & 0.4 & 0.5 & 0.3 & 1.4 & 1.6 & 0.7 & 1.4 & 1.6 & 0.5 & 2.5 & 3.0 & 0.5 \\
\hline 天然力゙ & 10 億 ${ }^{3} \mathrm{~m}$ & 2.1 & 2.0 & 1.4 & 2.4 & 2.3 & 0.9 & 2.9 & 2.8 & 0.8 & 2.9 & 2.8 & 0.5 \\
\hline 液化メタン & ガス 100 万 $\mathrm{t}$ & - & - & - & 0.2 & 0.3 & 0.1 & 0.7 & 0.9 & 0.3 & 0.7 & 0.9 & 0.2 \\
\hline 炭 & $"$ & 0.7 & 0.5 & 0.3 & 0.5 & 0.4 & 0.3 & 0.4 & 0.3 & 0.0 & 0.4 & 0.3 & 0.0 \\
\hline 薪 & $\begin{array}{l}100 \text { 万 } \mathrm{m}^{3} \\
(\text { 層積) }\end{array}$ & 15.5 & 23 & 1.6 & 13.3 & 2.0 & 0.8 & 12.1 & 1.8 & 0.5 & 10.0 & 1.5 & 0.3 \\
\hline
\end{tabular}

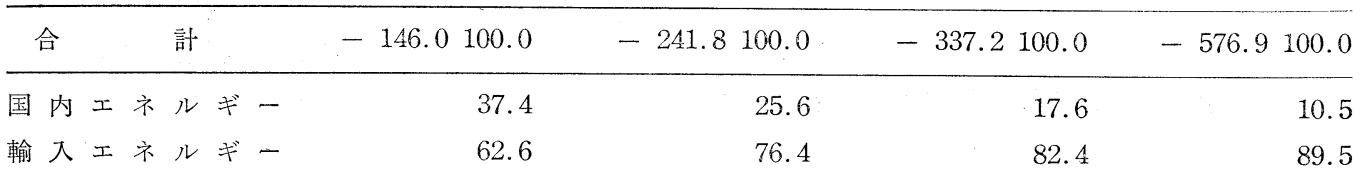

が，この間旧設備の老朽，珍鹰化による廃止能力もあ るので, 実際の追加必要能力はさらに大きくなる。い

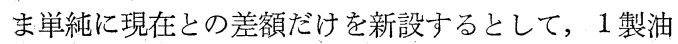
所の能力を平均25万b.b.1./日とすれば，10年間に11ケ 所, 20 年間に 24 ケ所の新製油所を建設する必要があ
る。

石油の低廉供給の使命を果すために, 製油所の集約 大型化をはかるとともに, 全国各地に分散する需要に 対し国内輸送コストを合理化するために，将来の製油 所をどこに新設することが効率的であるか，大口需要 
家とのコンビナート問題などとからみあつて, 石油工 場の将来の立地問題注, 地域経済開発計画上无関連し

て慎重な配慮が必要となる。

原油の品質と石油需給 原油の選択飞注, その原油 の供給力が十分あるか，安定的に供給されるか，その 性状が日本に適しているか，また若干の欠点があつて も輸出価格, 距離 (運賃) からして有利か不利かなど が重要な要件である。これらを総合すれば結局中東地 域が圮界の原浊の曾庫であることより，将来の入手源 の主力となることは明らかであり，インドネシヤ，ヴ エネズエラ，北アフリカ，カナダ，アラスカなどの 各原油は日本にとつては補完的な役割を果をなにすぎ ないと考えられる。

中, 重質の多い中東原油は, 日本の霝要構造からす れ代㧍兑和好ましいが，公害問題となつているイオ ウが多い点が最大の欠点である。したがつて重油の淔 接脱硫の技術開発が必要である。

原油の低廉安定確保 石油が日本経济の担い手とな つた今日，その安定供給体制が原油を輸入して国内で 精製することであるとするならば，原誼の輸入確保が 最重要事項であり, 原油価格の低廉化の促進をはかる ことが重要である。また積極的に海外原油を開発する ことは原油の直接確保のほか, 産油部門で得られる利 益も大きいので, 結局石油価格を低減させることに役 立つので促谁する必要がある。

さらに貯油能力の増強や邦船タンカーの拡充, 大型 化も安定確保の重要な鍵となるのでこれの早急実施が 望ましい。

$$
\text { VII, 㐫とがき }
$$

本論恰科学技術庁資源調查会エネルギー部会石油小
委員会 (委員長 日本石油精製(袜) 副社長 新并浩 氏）で現在とりまと的中の「世界の石油需給の動向」

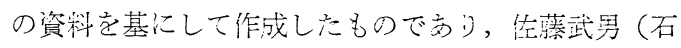
油連盟調查部長兼技術部長) 佐稼武部美 (日本エネ

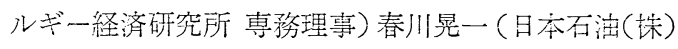
渉外室) 藤沼茂 (石油連盟技術潩是) 山田政利 (石油連盟技術課)の各氏の䩗筆丈案を多分に㳻用し てあることを腤記します。

\section{文献}

1）W. J, Levy，第 5 回世界石油会議第 4 部会第 3 論文

2) N. B. Goyal, 同上管 4 論文

3) P.R. R. Y. Chere, 同上第 4 部会第 5 䜽文

4) Oil \& Gas J. , Nov., 9 (1959)

5) 同上 Dec., 28 (1959)

6) Peiroleum times, Apr., 22 (1960)

7) Petroleum Week, May, 27 (1960)

8) P. P. S., Feb., 12 (1961)

9) Oil \& Gas J. , July, 23 (1962)

10) World oil, Apr., (1963)

11）国際石炭大会記録

12) P. I. Weekly, Jan., 6 (1964)

13) Oil \& Gas J., Apr., 11 (1963)

14) Platt (N), Nov., 13 (1963)

15) Platt $(N)$, Nov., 13 (1963)

16) P. I. Weekly, Dec., 3 (1953)

17) Platt $(N)$, Fed., 19 (1964)

18) Platt $(N)$, May, 21 (1964)

19) 第 6 回世界石油会議第 8 部会第 8 論文

20) World Petroleum, Jar. (1959)

21) World Oil, July (1962)

\title{
Trend of Supply and Demand of Petroleum in the World
}

\author{
by Tugio Murata
}

(Resources Bureau Science and Technology Agency)

SYNOPSIS:-Energy consumption is growing in the every district of the world today, and the growth of petroleum consumption is especially rapid, since liquid energy resources has the merit to be controlled easily. Japan depends its major part of energy supply on overseas resources because of scarcity of domestic ones. We realise, however, it is not easy to meet petroleum demand in the future, when we consider the deposits condition of petroleum resources in the world and $R / P$. It is therefore necessary to make still more effort for development of nuclear technology. economization of energy consumption and renovation of energy conversion technology as well as continuous obtainment of cheap petroleum. 